\title{
Policy Analysis of Indonesian Naval Depot Services in Surabaya
}

\author{
Sujianto ${ }^{1} \quad$ Suhirwan $^{2} \quad$ Lukman Yudho Prakoso ${ }^{3}$ \\ 1.Student of Sea Defense Strategy Study Program, Indonesia Defense University-Bogor, Indonesia \\ 2.Lecturer of Indonesia Defense University, Bogor-Indonesia
}

\begin{abstract}
The Indonesian Navy's Headquarters Supplies Office has an organizational structure which is divided into a supply center depot both in the western region in Jakarta and the eastern region in Surabaya. ship spare parts, every organization under the Indonesian navy must have elements or parts that handle the field of logistics or Logistics Staff. The Surabaya central supply depot is the supply depot in the central region which supplies demand for supplies starting from the second fleet and the third fleet. The task of the supply depot itself is receiving and storing and distributing supplies from the naval base, and ship units. This study aims to conduct an analysis of the quality of service in the Indonesian naval depot in Surabaya. This study uses a scientific approach with qualitative descriptive methods and uses the theory of implementation from George C. Edward III. The results of this study on the communication factor required an accuracy in the delivery of stock information; optimization of resource factors needed; disposition factors required open attitude of all personnel towards the advancement of information technology; and bureaucratic structure factors required clear Operating Standards and Procedures (SOPs). The conclusion of this study is that an integrated service system is needed by developing communication factors, resources, attitudes and bureaucratic structures optimally.
\end{abstract}

Keywords: Supplies, naval depot, integrated service system

DOI: $10.7176 / \mathrm{PPAR} / 10-3-05$

Publication date:March $31^{\text {st }} 2020$

\section{Introduction}

The word logistical comes from the Greek logos ( $\lambda$ ó $\left.{ }^{\circ} \varsigma\right)$ which means "ratio, word, calculation, reason, speech, oration". The logistical word has the origin of the word loger from French, which is to imply or provide. Its original use is to explain the science of movement, supply \& care of military forces in the field. Later it is used to describe the flow management of goods in an organization, from raw goods to finished goods. Logistics is a concept that is considered to have evolved from the military's need to fulfill their supplies as they moved to the battlefield from headquarters. In the ancient Greek, Roman and Byzantine empires, there were military officers with the title 'Logistikas', who were responsible for the distribution and funding of war supplies (Kairul, 2017).

The Navy's development policy outlined in the Navy Chief of Staff Regulation No. Perkasal / 24 / IV / 2011 dated 19 April 2011 regarding the basic policy of the development of the Navy towards the Minimum Essential Force (MEF) provides clear direction for Navy development going forward. To achieve the expected goals, it is necessary to conceptually harmonize between all fields optimally. Development policy in the supply sector with available resources must be able to support the development of the Navy as a whole.

Indonesian Navy depot in Surabaya as the Technical Implementation Unit of the Navy's Procurement Service is part of the Navy's supply chain management management demanded to be able to carry out its role in carrying out the distribution of supplies on time, in numbers and targets to user units.

In military logistics, logistics officers manage how and when to move resources to where they are needed. Supply chain management in military logistics usually intersects with certain variables to predict costs, deterioration in quality, consumption and future demand. The grouping of categories, namely the classification of supplies, is developed in such a way that supplies with similar consumption categories are grouped into separate groups for the purpose of further planning. For example, consumption in peacetime for ammunition and fuel will be less than during war, where other supplies such as food and clothing have a constant consumption ratio regardless of war or peace. Troops will always need uniforms and food, more troops means more food and uniforms.Manajemen logistik merupakan bagian dari proses supply chain yang berfungsi untuk merencanakan, melaksanakan, dan mengendalikan keefisienan dan keefektifan penyimpanan dan aliran barang, pelayanan dan informasi terkait dari titik permulaan (point of origin) hingga titik konsumsi (point of consumption) dalam tujuannya untuk memenuhi kebutuhan para pelanggan (Budi,2019).

Management Information System is an integrated system between humans and machines that are able to provide information in such a way as to support the course of operations, the course of management and decisionmaking functions within an organization. The system uses hardware and software (software and hardware), manual procedures, models for analysis, planning and decision making are also databases, (Budi, 2019) the information structure includes:

a. Transactions that must be processed include purchase requests, purchase orders, production orders, receipt reports, supply signs, transportation requests, and transport documents. 
b. Operational control, using information contained in lists and reports such as previous purchases, previous deliveries, goods not in inventory, excess goods, inventory turnover reports, sales achievement summaries, and transportation performance analysis.

c. Control Information Information for logistics consists of a comparison between the level of inventory planned and actual, the purchase price of goods, turnover and so on.

d. Strategic planning involves a new distribution analysis, new policies related to sales, and a make or buy strategy. Information about new technologies, distribution alternatives, and so on, becomes necessary.

Computer technology which is a supporter of information systems is very fast changing and vice versa is not supported by the development of the concept of the information system itself which tends to develop slowly. This is due to changes in the capacity and cost of the hardware and software used by the system. Computer technology which is a supporter of information systems is very fast changing and vice versa is not supported by the development of the concept of the information system itself which tends to develop slowly. This is due to changes in the capacity and cost of the hardware and software used by the system. It is emphasized that the identification of information needs only then establishes a system that meets those needs. This is due to the fact that each function of the organization and individual decision makers in it differ in the needs and utilization of information. but with the development of hardware, software, and of course the information system method opens opportunities for managers to have a system in accordance with the critical decisions that must be taken. This is very important especially for managers in logistics who are directly dealing with markets that are always vulnerable to change Maximizing IT Functions in Logistics Management/SCM.

\section{Research Methods and Theories}

This research uses descriptive qualitative method, the theory used is Goerge C. Edwards III theory with four factors namely; Communication Factors Determination of an action or activity that is expected to go through good communication and continuity so that it takes an accuracy in the delivery of information. Resource Factors: Resources are needed to improve the quality of the organization both personnel and material and supporting devices. Disposition; A desire, ability and tendency of policy makers to carry out and realize the policy seriously; Bureaucratic Structure: Bureaucratic structure which includes fragmentation as well as Operating Standards and Procedures (SOP) in an organization must be implemented clearly (Edward III, 1980).

\section{Analysis of the Discussion}

From the research conducted at the Navy depot, it can be said that there is no effective and efficient system yet regarding Requests to Receive and Requests to Deliver. This can be seen from the results of data management with the theory of George C. Adward III as follows:

\subsection{Communication Factors}

The Navy depot in serving the demand for goods from a lower unit both the pendirat and Navy Ship interact directly, both through communication tools and come directly to The Navy depot. Information regarding the availability of goods needed by the lower unit is difficult to know with certainty. While the Navy ship elements that will operate require speed and accuracy of the parts used. Therefore, it is needed an accuracy in the delivery of available information available by developing an information system that can be easily assessed by every element of the navy shipI and the Landing Unit in the naval depot working area, so that communication can be carried out effectively and efficiently.

\subsection{Resource Factors}

The ability of personnel to provide the services carried out is still using the conventional method of checking the availability of spare parts. This results in users having to come to the warehouse to see first hand the availability of spare parts needed, so that it will spend a lot of time and effort. Considering these conditions, it would be better to use the method used in checking the availability of spare parts using information technology. Therefore it is necessary to prepare professional and support personnel with adequate infrastructure.

\subsection{Disposition/Attitude}

Every personnel who are in The Navy depot are mostly nearing the end, so it is difficult to move from a conventional service system to the development of modern information technology. This is shown from the attitude and behavior of the personnel who work in navy depot feel more comfortable in a professional way.

It is expected that in the future there will be a change of personnel to accept the advancement of modern information technology. To achieve this, it is necessary for the supply crew at navy depot to be filled little by little by personnel who are still stressful and fresh in thought and energy. Because training is needed in the preparation of human resources and it is expected that each personnel can fill themselves with technological developments so they do not feel awkward and operate computers. 
By increasing the number of exercises it is hoped that they will be accustomed especially in relation to infrastructure or software such as existing computer applications that often change with the needs of the organization itself.

\subsection{Bureaucratic Structure}

An activity carried out in carrying out a series of tasks ranging from the demand for goods until the goods are received by the user. The flow of bureaucracy in Navy depot is still complicated and not one door. It is hoped that an SOP will be made that will cut through complicated and complicated bureaucratic pathways so that it becomes more effective and efficient. If this can be applied, the process of requesting up to receipt of goods can be carried out faster and more precisely.

So that the integrated supply service system can contribute to the effective operation of the service as expected

\section{Conclusion}

From the results of the research, it can be concluded that the services applied in Navy depot are still low so that there is a need for improvement in service delivery both in terms of:

a. Communication Factors, in the provision of interaction services needed by both the landing unit and navy ship, to be more effective and efficient can use a modern information system that can access the contents of the supply warehouse to make it easier for each stock user to find spare parts needed.

b. Resource Factor, services that are still conventional will result in the time from implementing the provision of provisions will require a long time so that we need a modern information system in order to be able to advance the user unit stock can be faster to get the supplies needed.

c. Disposition, many employees have entered the retirement period so there is a need to fill new personnel and master the information system that can facilitate more effective and efficient services.

d. Bureaucratic structure, there are still many winding bureaucratic defects that will lead to a long process in counterfeit requests so that the need to trim bureaucracy into one door so that the demand for supplies is faster in its handling.

\section{References:}

Budi Kho (2019), https://ilmumanajemenindustri.com/pengertian-manajemen-logistik-logistic-management/, Accesed at February, 2020

Edwards III, George C. 1980. Implementing Public Policy. Washington: Cogressional Quaerterly Inc

Khairul Janwar (2017), https://edulogistik.com/2017/05/09/manajemen-logistik-definisi-sejarah-singkat/, Accesed at Februari 19, 2020.

Navy Chief of Staff Regulation No. Perkasal / 24 / IV / 2011 dated 19 April 2011 regarding the basic policy of the development of the Navy towards the Minimum Essential Force (MEF) 